\title{
Efektivitas Pemberian Terapi Suportif dalam Menurunkan Ansietas pada Remaja
}

\author{
Edo Gusdiansyah'1, Weni Mailita ${ }^{1}$, dan Yuanita Ananda ${ }^{2}$ \\ 1STIKes Alifah Padang. Jl. Khatib Sulaiman No 52B Kelurahan Belanti, Padang, 25136. Indonesia \\ 2Fakultas Keperawatan, Universitas Andalas, Kampus Limau Manis, Padang, 25163. Indonesia \\ E-mail: edo.gusdiansyah@gmail.com
}

Keywords:

adolescents

anxiety,

supportive

therapy

Kata Kunci:

ansietas, remaja,

terapi suportif

\begin{abstract}
Mental disorders are behavioral or psychological patterns shown by individuals that cause distress, dysfunction; reduce the quality of life which becomes a psychosocial problem. Psychosocial problems that result in social changes in society can cause mental disorders. The prevalence of adolescents in Indonesia experiencing psychosocial problems is $8.7 \%$. In West Sumatra Province, the population is 5.48 million with a number of teenagers around 511.8 people. Of these, one in five adolescents has psychosocial problems that require adequate and special treatment. The solution to this problem is by providing supportive therapy which aims to help deal with mental health problems that exist in the community. This activity was carried out on February 3, 2021 with a total of 20 teenagers. The results of the evaluation show that there is a change in anxiety in adolescents. Suggestions for the health center are to monitor the results of this education.
\end{abstract}

\section{ABSTRAK}

Gangguan jiwa merupakan pola perilaku atau psikologis yang ditunjukkan oleh individu yang menyebabkan distres, disfungsi, menurunkan kualiatas kehidupan yang menjadi masalah psikososial. Masalah psikososial yang berakibat adanya perubahan sosial dalam masyarakat yang dapat menimbulkan gangguan jiwa. Prevalensi remaja di Indonesia yang mengalami masalah psikososial sebesar 8,7\%. Di Propinsi Sumatera Barat jumlah penduduk yaitu 5,48 juta jiwa dengan jumlah remaja sekitar 511,8 jiwa. Dari jumlah tersebut satu diantara lima remaja memiliki masalah psikososial yang memerlukan penanganan yang memadai dan khusus. Oleh karena itu, sangat diperlukan sekali metode untuk pemberian terapi suportif kepada remaja yang bertujuan untuk membantu menangani masalah kesehatan jiwa khususnya kepada masalah kecemasan. Pelaksanaan terapi suportif dilakukan dalam 4 sesi. Kegiatan ini dilakukan pada tanggal 3 Februari 2021 dengan jumlah peserta 20 remaja. Hasil evaluasi menunjukkan bahwa terjadi penurunan ansietas pada remaja pada saat pretest dan posttest. Saran untuk pihak puskesmas yaitu melakukan monitoring terhadap hasil edukasi ini. 


\section{PENDAHULUAN}

Menurut World Health Organitation (WHO, 2018) kesehatan jiwa adalah suatu keadaan sejahtera yang dikaitkan dengan kebahagiaan, kegembiraan, kepuasan, pencapaian, optimisme atau harapan. Gangguan jiwa merupakan pola perilaku/psikologis yang ditunjukkan oleh individu yang menyebabkan distres, disfungsi, menurunkan kualitas hidup yang menjadi masalah psikososial (Keliat, B. A dan Pasaribu, 2016). WHO (2018) memperkirakan 450 juta orang seluruh dunia mengalami gangguan mental/psikososial sekitar $10 \%$ orang dewasa dan 25\% pada usia tertentu. Menurut National Institute of Mental (NIMH, 2019) penduduk Amerika tahun 2014 memperkirakan 26,2\% yang berusia remaja mengalami masalah psikologis dan gangguan jiwa. Berdasarkan Riskesdas (2018) prevalensi remaja di Indonesia yang mengalami masalah psikososial sebesar 8,7\%. Di Propinsi Sumatera Barat jumlah penduduk yaitu 5,48 juta jiwa dengan jumlah remaja sekitar 511,8 jiwa. Dari jumlah tersebut satu diantara lima remaja memiliki masalah psikososial yang memerlukan penanganan yang memadai dan khusus.

Remaja merupakan masa dimana individu rentan terhadap terjadinya masalah psikososial karena adanya perubahan yang terjadi meliputi perubahan biologis, kognitif, dan sosial emosional (Steinberg, 2017). Perubahan tersebut membuat remaja menjadi pribadi yang penuh gejolak emosi serta dipenuhi ketidakseimbangan sehingga mudah terpengaruh oleh lingkungan yang membawa remaja berurusan dengan lembaga hukum dan berada di rumah tahanan sebagai narapidana (Masngudin, 2018). Setiap tahunnya terdapat lebih dari 4.000 perkara pelanggaran hukum yang dilakukan oleh remaja yang diserahkan ke pengadilan dan 83\% dari mereka dipenjarakan. Hingga saat ini, terdapat 4,722 anak didik di LAPAS Anak dengan kasus terbanyak adalah pencurian (60\%) dan perkelahian (13\%) (Departemen Kehakiman dan HAM, 2018).

Remaja yang terlibat masalah kenakalan mengakibatkan akan berurusan dengan masalah hukum mengakibatkan remaja mengalami ansietas (Atmasasmita, 2019). Hal ini diperkuat oleh penelitian yang dilakukan oleh Collins, dkk (2017) yang menyebutkan bahwa 20,3\% remaja yang menjalani masa hukuman mengalami ansietas. Upaya yang dilakukan untuk menurunkan tingkat ansietas yaitu menggunakan terapi suportif. Terapi suportif merupakan terapi yang berbasis psikatrik untuk memahami bagaimana seseorang dapat berubah (Viederman, 2017). Pada remaja di rumah tahanan dengan ansietas, terapi suportif sangat membantu menjelaskan tentang respon koping biopsikososial, mengenal sumber koping dan menggunakan sumber koping yang telah diidentifikasi untuk mengatasi ansietas yang dialami sehingga dapat dicegah atau dikurangi yang bertujuan untuk membantu menangani masalah kesehatan jiwa yang ada di masyarakat khususnya adalah memberikan teknik terapi suportif untuk menurunkan tingkat kecemasan pada remaja (Lipsitz, 2019).

\section{METODE}

Metode pelaksanaan kegiatan yang akan dilakukan untuk mengatasi masalah mitra yaitu masyarakat (remaja) belum mampu melakukan cara mengatasi tingkat kecemasan dan kurangnya pengetahuan masyarakat (remaja) tentang kesehatan jiwa baik khususnya masalah psikososial. Metode yang digunakan untuk megatasi masalah tersebut adalah dengan pemberian terapi suportif selama 4 kali pertemuan, yaitu:

\section{Pertemuan 1}

Mengidentifikasi kemampuan remaja dan sistem pendukung yang dimiliki oleh remaja. Hal ini dilakukan dengan cara diskusi dengan remaja mengenai; apa yang diketahuinya tentang masalah yang sering dialami oleh remaja, cara mengatasi masalah, dan sumber pendukung 
yang ada dan memberi motivasi untuk mengungkapkan pendapat dan pikiran terhadap masalah yang dialami remaja.

2. Pertemuan 2

Bagaimana remaja menggunakan sistem pendukung, monitor hasil, dan hambatannya, yaitu mendiskusikan dengan remaja mengenai kemampuan positifnya menggunakan sistem pendukung internal remaja (mekanisme koping konstruktif, motivasi, harapan) dan hambatannya, melatih serta meminta remaja untuk melakukan demonstrasi menggunakan sistem pendukung internal dengan melibatkan anggota kelompok lainnya.

3. Pertemuan 3

Bagaimana remaja mengakses berbagai sumber dukungan eksternal, monitor hasil dan hambatannya. Yaitu mendiskusikan dengan remaja mengenai kemampuan positifnya menggunakan sistem pendukung eksternal dan hambatannya, melatih serta meminta remaja untuk melakukan demonstrasi menggunakan sistem pendukung eksternal dengan melibatkan anggota kelompok lainnya.

4. Pertemuan 4

Bagaimana remaja mengevaluasi penggunaan sumber. Pada sesi ini yang dilakukan adalah mengevaluasi pengalaman yang dipelajari dan pencapaian tujuan, mendiskusikan hambatan dan kebutuhan yang diperlukan berkaitan dengan penggunaan sumber pendukung yang ada baik internal maupun eksternal dan cara memenuhi kebutuhan tersebut, serta mendiskusikan kelanjutan dari perawatan setelah program terapi.

\section{HASIL DAN PEMBAHASAN}

Pengabdian masyarakat ini dilakukan pada tanggal 3 Februari 2021 dilaksanakan di wilayah kerja Puskesmas Kuranji Padang dengan jumlah peserta 20 Remaja yang mengalami masalah ansietas. Tim dosen yang melakukan edukasi yaitu Ns. Edo Gusdiansyah, M.Kep, Ns. Weni Mailita, M.Kep dan Ns. Yuanita Ananda, M.Kep serta dibantu oleh 3 orang mahasiswa. Penyaji dan tim memberikan penyuluhan tentang "Efektivitas Pemberian Terapi Suportif dalam Menurunkan Ansietas pada Remaja". Setelah itu dilanjutkan dengan pemberian terapi suportif yang membuat remaja dibagi menjadi 4 kelompok dengan menggunakan buku kerja dan setiap kelompok diberikan terapi suportif dalam 4 kali pertemuan. Kegiatan ini diikuti dengan antusias oleh masing-maisng remaja. Selama kegiatan berlangsung penyaji dan Tim berbagi tugas demi kelancaran proses penyuluhan dan pelaksanaan terapi. Moderator membagi sesi penyuluhan dengan penyajian dan sesi tanya jawab begitu juga saat melakukan terapi suportif. Kegiatan ini juga dibutuhkan oleh pihak puskesmas dan remaja demi kelancaran proses menurunkan tingkat kecemasan pada remaja dengan pemberian terapi suportif. Adapun karakteristik remaja yang mengikuti kegiatan ini ditampilkan pada Tabel 1. 
Tabel 1. Karakteristik Remaja yang Mengikuti Penyuluhan

\begin{tabular}{lcc}
\hline \multicolumn{1}{c}{ Karakteristik } & Frekuensi & Persentase (\%) \\
\hline Umur & & \\
1. Remaja Awal & 8 & 40 \\
2. Remaja Akhir & 12 & 60 \\
\hline Jenis kelamin & & \\
1. Laki-laki & 15 & 75 \\
2. Perempuan & 5 & 25 \\
\hline Pendidikan Terakhir & & \\
1. S2 & - & 20 \\
2. S1 & 4 & 65 \\
3. SMA & 13 & 15 \\
4. SMP & 3 & \\
\hline Agama & & 100 \\
1. Islam & 20 & \\
\hline
\end{tabular}

Dari tabel diatas dapat dilihat bahwa sebagian besar masyarakat yang mengikuti program edukasi adalah berusia remaja akhir (60\%), mayoritas berjenis kelamin laki-laki (75\%), sebagian besar memiliki pendidikan SMA (65\%) dan seluruhnya beragama Islam $(100 \%)$.

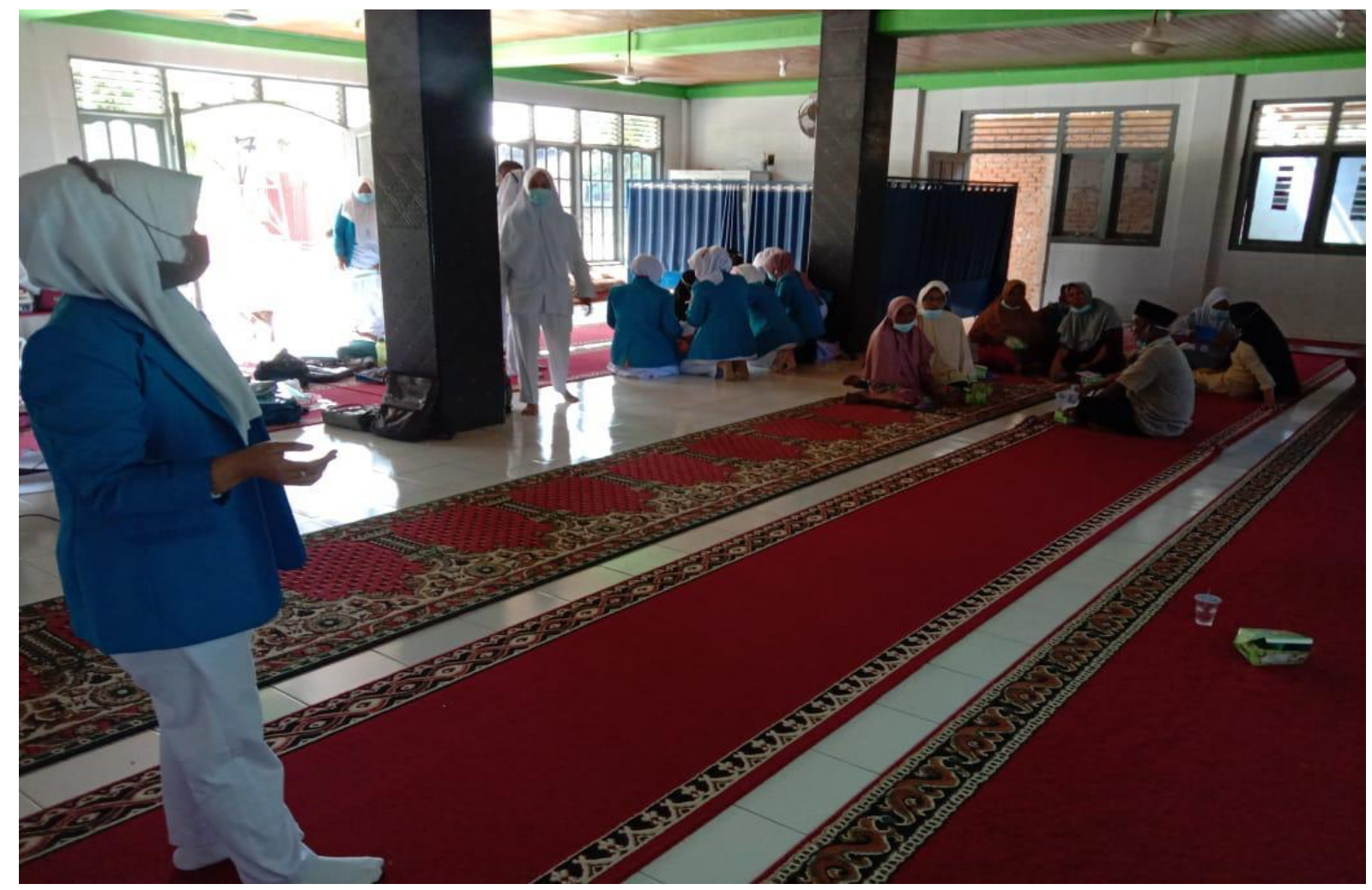

Gambar 1. Kegiatan Pemberian Terapi Suportif kepada Remaja dalam Kelompok 


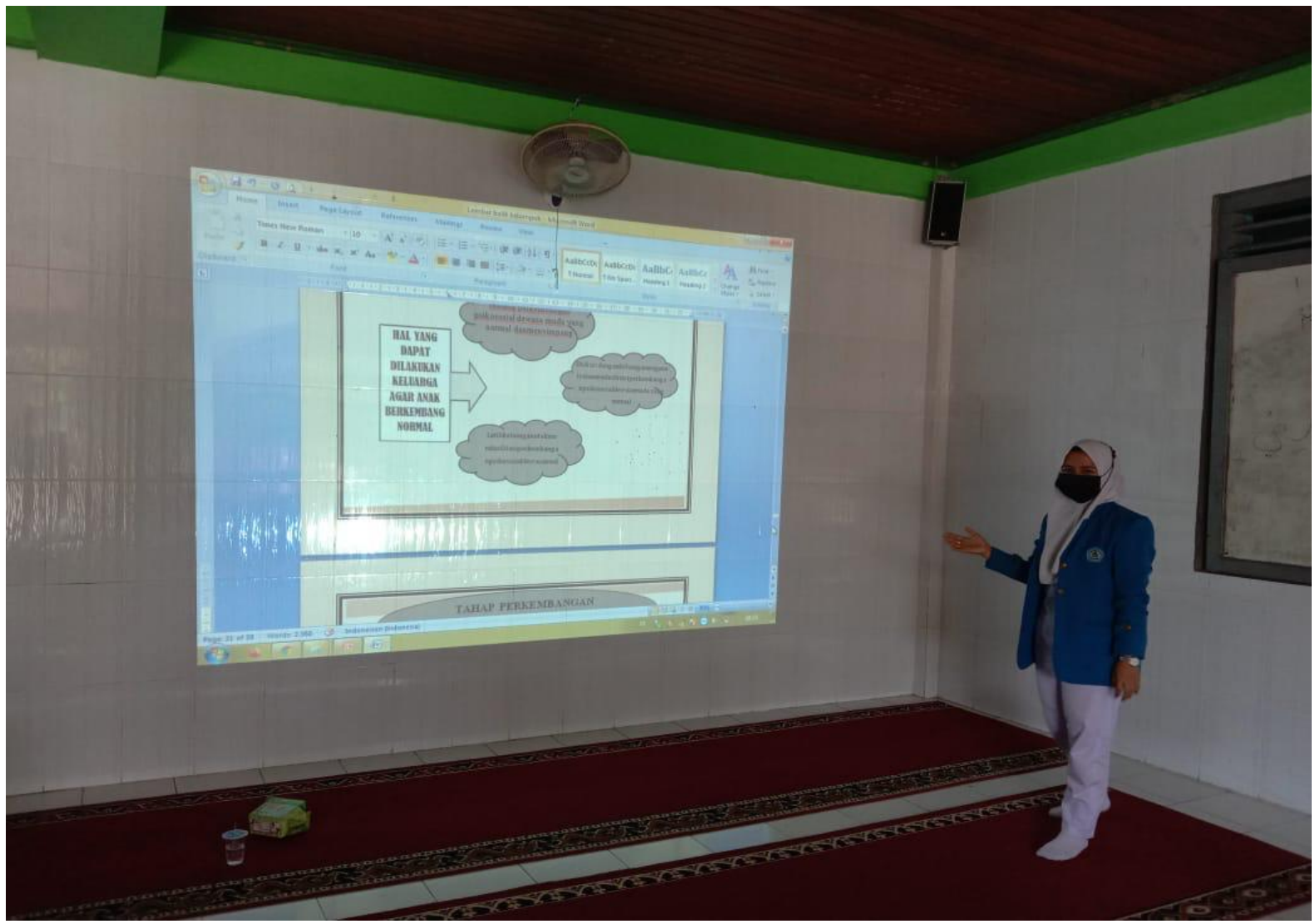

Gambar 2: Kegiatan Pemberian Edukasi kepada Remaja

\section{KESIMPULAN}

Edukasi yang diberikan kepada remaja sangat efektif dilakukan untuk menurunkan ansietas. Hal ini terlihat dari pemahaman remaja tentang terapi suportif dan aplikasinya. Kegiatan ini dapat dilakukan secara berkelanjutan dengan cara kerja sama dengan pihak Puskesmas Kuranji Padang dengan cara melakukan controlling kepada remaja. Kegiatan ini dapat membantu pemerintah dalam upaya menurunkan ansietas pada remaja dan mencegah kenakalan remaja. Kerja sama semua pihak merupakan keberhasilan kita bersama dalam menurunkan angka ansietas pada remaja.

\section{UCAPAN TERIMA KASIH}

Terimakasih kepada UPPM STIKes Alifah Padang sebagai penyandang dana sehingga kegiatan edukasi ini terlaksana dengan baik. Selanjutnya kepada Pihak Puskesmas Kuranji Padang yang telah memberikan ijin sehingga kegiatan ini dapat terlaksana.

\section{DAFTAR PUSTAKA}

Atmasasmita. (2019). Sistem Peradilan Pidana: Perspektif Eksistensialisme Dan Abilisionisme (Cet II Rev). Bandung: Bina Cipta. 
Collins, O. (2017). Psychiatric Disorder In Detained Male Adolescents: A Systematic Literatur Review. The Canadian Journal Of Psychiatric, 55 (4), 255-263.

Departemen Kehakiman \& HAM. (2018). Jumlah Kasus Pelanggaran Hukum Yang Dilakukan Remaja.

Depkes RI. (2017). Jumlah Remaja yang Mengalami Masalah Psikososial.

Friedman, Marilyn M., Bowden, V.R., \& Jones, E.G.(2018). Buku Ajar KeperawatanKeluargaRiset, Teori Dan Praktik.Alih Bahasa, AchirYani S. Hamid, dkk; Editor Edisi Bahasa Indonesia, EstuTiar. - Ed.5th Jakarta: EGC.

Keliat, B.A dan Pasaribu. (2016). Prinsip dan Praktik Keperawatan Kesehatan Jiwa Stuart. Singapura. Elsevier.

Lipsitz, J. D., E. Al. (2018). A Randomized Trial Of Interpersonal Therapy Versus Supportive Therapy For Social Anxiety Disorder. Depression And Anxiety, 25 (6), 542-553.

Masngudin. (2014). Kenakalan Remaja Sebagai Perilaku Menyimpang Dan Hubungannya Dengan Keberfungsian Sosial Keluarga. Departemen Sosial.

Nanda. (2019). Diagnosis Keperawatan Defenisi \& Klasifikasi 2015-2017 Edisi 10 Editor T Heather Herdman, Shigemi Komitsuru. Jakarta: EGC.

National Institute Of Mental Health (NIMH). (2015). Anxiety Disorder: Risk Factors And Diagnosis.

Notoatmodjo. (2012). Promkes Dan PerilakuKesehatan. Jakarta: RinekaCipta.

Riset Kesehatan Dasar (RISKESDAS). (2018). Badan Penelitian dan Pengembangan Kesehatan, Departemen Kesehatan, Republik Indonesia: Jakarta.

Saddock, B.J dan Saddock, V. . (2018). Kaplan and Saddock's Synopsis of Psychiatry: Behavioral Science/Clinical Psychiatry (10 Th Ed). Lippincott William \& Wilkins.

Soetjiningsih. (2014). Tumbuh Kembang Remaja dan Permasalahannya. Jakarta: CV Sagung Seto.

Steinberg, L. (2012). Cognitive And Affective Development In Adolescense. Trend In Cognitive Science. Handbook Of Parenting, 9 (2), 69-74.

Stuart,G.W. (2016). Principles and Practice of Psychiatric Nursing. (9th Ed). Missouri: Mosby Elsevier.

Townsend, M. C. (2019). Psychiatric Mental Health Nursing (6 th Ed). Philadelphia: Davis Company.

Videbeck, S. L. (2017). Psychiatric Mental Health Nursing (4 rd Ed). Philadelphia: Lippincot Williams \& Wilkins. 
Viederman, M. (2018). A Model For Interpretative Supportive Dynamic Psychotherapy. Psychiatric, 71 (4), 349-358.

World Health Organization (WHO). (2018). World Health Statistic. Geneva 27. 